\title{
Causal factors underlying the dramatic decline of the Sumatran orang-utan
}

\author{
J. M. Yarrow Robertson and Carel P. van Schaik
}

\begin{abstract}
The Sumatran orang-utan is in dramatic decline, including the population in its main stronghold, the Leuser Ecosystem, in Sumatra, Indonesia (C. P. van Schaik et al. (2001) Oryx 35, 14-25). The major threats to the survival of Sumatran orang-utans are identified as habitat loss (mainly from conversion to oil palm plantations), habitat degradation and habitat fragmentation. The immediate causes of this are identified as weak compliance with regulations and laws; weak law enforcement and the weak legal environment. Corruption is identified as the ultimate causal factor underlying these three immediate causal factors, along with a frontier mentality and bureaucratic constraints. Together, they have resulted in the destruction of prime orang-utan habitat. Several political actions are recom-
\end{abstract}

mended to improve the effectiveness of habitat conservation for the orang-utan and several technical challenges are to be overcome once the policy context is right. The most crucial problem to solve is the lack of regular funds for enforcement operations and establishing a new system of enforcement that is effective. In addition, the Gunung Leuser National Park needs to be redesigned by enlarging it to cover all high biodiversity areas within the Leuser Ecosystem. Moreover, habitat corridors between important forest tracts need to be re-established.

Keywords Corruption, illegal logging, Leuser Ecosystem, orang-utan, policy, Sumatra.

\section{Introduction}

The Sumatran orang-utan population has suffered 86 per cent loss over the last 100 years (Rijksen \& Meijaard, 1999). In its main stronghold, the Leuser Ecosystem (Sumatra, Indonesia), the Sumatran orang-utan is currently in dramatic decline, with a loss of over 1000 orang-utans every year (van Schaik et al., 2001). If this trend continues, the Sumatran orang-utan will become ecologically extinct in the wild within the next 10 years (van Schaik et al., 2001).

In most areas and for many centuries, hunting for subsistence or trade was the major threat to orang-utan populations (Rijksen \& Meijaard, 1999; Delgado \& van Schaik, 2000). In the Leuser Ecosystem no aboriginal tribes lived in the forest during historic times. People around Leuser were primarily agriculturalists, whose very limited impact on orang-utans was through timber extraction for subsistence needs, for houses and dugout canoes, and through habitat disturbance because of shifting cultivation.

J. M. Yarrow Robertson (Correspondence) Wildlife Research Group, Department of Anatomy, Cambridge University, Downing Street, Cambridge CB2 3DY, UK. E-mail: yarrow@attglobal.net

Carel P. van Schaik Department of Biological Anthropology and Anatomy, Duke University, Box 90383, Durham, NC 27708-0383, USA., and Wildlife Conservation Society, Asia Program, Bronx, NY 10460, USA

Revised manuscript accepted for publication 7 September 2000
The serious threats in this area, as almost everywhere else at present, come from commercial logging. Hence, efforts to protect orang-utans must focus on habitat protection. In particular, conserving wild Sumatran orang-utans requires protecting tracts of unexploited forest that are interconnected and contain a significant proportion of lowland and floodplain habitat (Delgado \& van Schaik, 2000; van Schaik et al., 2001).

In this paper, we review current efforts to protect the Sumatran orang-utan from extinction, and based on an analysis of the causes for their continuing decline, develop a set of recommendations for conservation.

Before doing so, we should point out that these developments and conservation efforts take place against a backdrop of economic and political turmoil. The Asian financial crisis hit Indonesia's economy so hard that, by 1998, violent demonstrations forced longterm president Soeharto to resign. This change ushered in a period of near-anarchy, during which illegal activities became rampant. For instance, by 1999, illegal logging in Indonesia had overtaken legal logging operations (EIA/Telapak, 1999; Purnomo, 2000). By October 1999, a new democratically-elected government had taken office. Meanwhile, in the special province of Aceh in northern Sumatra, long-standing separatism had escalated into large-scale armed conflict. The lawlessness, especially in Aceh, clearly exacerbated some of the existing problems. The government hoped that implementation of the new law on regional 
autonomy in 2001 would help resolve some of these problems. We believe, however, that the recommendations developed here will be valid regardless of the developments in this conflict.

\section{Management of the Leuser Ecosystem}

In the early 1990s, Leuser's orang-utans received insufficient protection because of inadequate design of the original protected area (Gunung Leuser National Park), and serious deficiencies in conservation and land-use planning in the broader region. The park is large (c. $9000 \mathrm{sq} \mathrm{km}$ ) and rich in endemics. It harbours the only potentially viable population of the critically endangered Sumatran rhino (IUCN/SSC, 1997), now thought to be the most endangered large mammal on earth due to a critically low and dispersed population (van Strien, pers. comm.). It contains mainly montane areas which covers only a small proportion of prime habitat for orang-utans and many other lowland elements, including the Sumatran elephant and the Sumatran tiger (Rijksen \& Griffiths, 1995). The park was insufficiently protected, with extensive illegal extraction of timber and poaching, as well as conversion and illegal settlements. Almost all the valuable areas outside the park were being selectively logged or converted into plantation or transmigration areas. As there is a trend toward systematic conversion of logging concessions into permanent agriculture, it was feared that very little prime habitat would remain within a decade or so.

To remedy these inadequacies, the Leuser Ecosystem was proposed: an area of approximately $25,000 \mathrm{sq} \mathrm{km}$ in northern Sumatra. It encompasses the designated Gunung Leuser National Park (see Fig. 1) and will contain a redesigned and enlarged future national park. In recognizing the global importance of the Leuser Ecosystem, the Government of Indonesia and the European Commission (EC) entered into a 7-year partnership, integrated conservation and development project (ICDP), called Leuser Development Programme (LDP). The rationale for the programme and the detailed planning which went into it are outlined in Rijksen \& Griffiths (1995) and the LDP overall work plan (Leuser Development Programme, 1997). The objective of the LDP is to conserve the Leuser Ecosystem, and in so doing, secure the basis for sustainable development in the surrounding regions.

The LDP is to achieve these objectives through two broad sets of activities: (i) establishing and conserving a new nature conservation area within ecologically sustainable boundaries, leaving its biodiversity intact to the full extent and (ii) facilitating sustainable development of buffer zones inside the ecosystem and of the intensive production area surrounding it. Thus, encroachment or unsustainable exploitation affecting the ecosystem will be redirected towards alternative sustainable income-generating opportunities in the intensive production area. Quid pro quo agreements with local communities, whereby ecologically-sound developments could be supported in exchange for conservation guarantees, were to be instrumental in bringing about this shift in the nature of activities.

Key elements of the programme are the integration of the ecosystem into the government's spatial landuse planning process (implemented by Bappeda, the provincial- and regency-level development planning board), as well as the involvement of local communities, local government and NGOs in implementing the programme's activities (Monk \& Purba, in press). A major initiative is the development of eco-tourism, including orang-utan viewing. Further details can be found on LDP's website at www.ec-ldp.co.id.

The Government of Indonesia also recognized the opportunity to privatize management of the Leuser Ecosystem. The threats to Leuser are a complex mix of legal and illegal components, emanating from business, government and local interests, taking place in an everchanging political landscape. Hence, privatized management, less subject to bureaucratic constraints, should be more creative, flexible and responsive. Accordingly, the right to manage the conservation of the Leuser Ecosystem was granted to a local NGO, the Leuser International Foundation (LIF), for 30 years.

LDP is implemented by a technical management body, Leuser Management Unit (LMU), that implements the LDP. After the programme ends, the management will revert to LIF, which will retain an implementing body much like LMU. One of the tasks of LMU is to support the development of LIF to ensure its professional capacity to execute its mandate effectively. In the long run, the LIF needs to attain financial autonomy through a substantial trust fund established by international donors.

The programme has scored considerable conservation successes (The World Bank, 1997; Griffiths \& van Schaik, unpublished data), but it has not been able to prevent the many destructive developments that threaten the orang-utan's survival in the Leuser Ecosystem. The loss of orang-utan habitat has been quantified elsewhere (van Schaik et al., 2001). In this study, we describe the processes of habitat destruction and analyse their underlying causes. We will identify political factors external to the programme as the major causes, thus explaining LDP's inability to conserve Sumatran orangutans fully in spite of achieving considerable political support. 


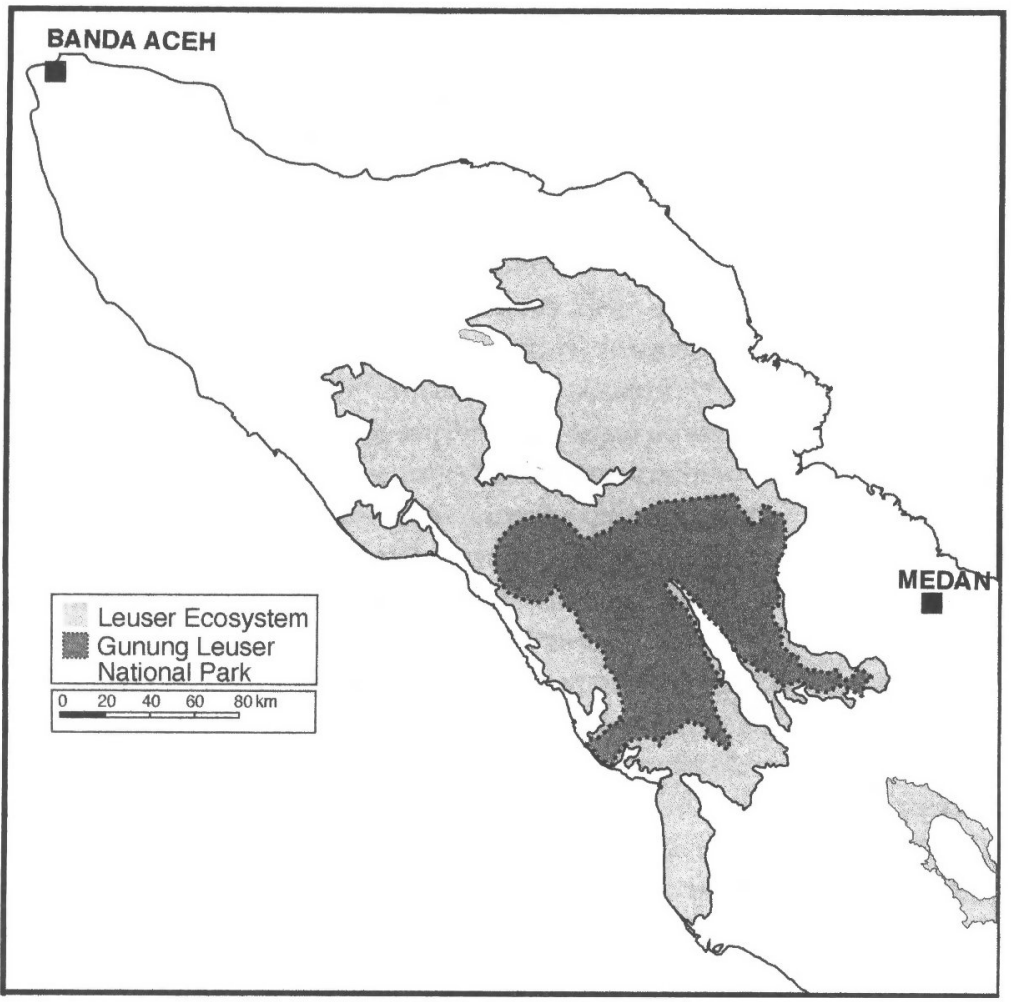

Fig. 1 Position of the designated Gunung Leuser National Park within the Leuser Ecosystem. The main areas and rivers are shown in the companion article (van Schaik et al., 2001).

\section{Destructive processes}

The three main processes threatening populations of orang-utans and those of many other forest species are habitat loss, degradation and fragmentation.

Habitat loss is caused by forest conversion to permanent agriculture, both legally or semi-legally for plantation estates and also illegally by local encroachment. Habitat degradation is mainly caused by timber extraction. Habitat fragmentation mainly comes in two different forms. First, forest is being cleared up slopes leaving forest islands contouring tops and fringing ridges. If only strips are cleared up slopes but beyond the altitudinal limit of orang-utans, it can still lead to habitat fragmentation although the forest is still contiguous at higher altitude. Second, roads in this region are inevitably accompanied by forest clearing in a strip along them, and sever links between major forest blocks. Fragmentation is a by-product of habitat loss and degradation. Thus, controlling the latter also reduces the former, but minimizing fragmentation also requires an emphasis on preventing the building of roads through sensitive areas because encroachment and settlement along them cannot be avoided. Reestablishing major habitat corridors, therefore, sometimes necessitates either land purchase or compensation packages. Further details of this are given in Robertson \& van Schaik (in press). From here on, we will focus on the processes producing habitat loss and degradation.

The destructive processes occur throughout the Leuser Ecosystem, both within protected areas and in other forest categories on state forest land (Fig. 2). The players in these processes are (i) companies operating legally in timber concessions or agricultural estates, (ii) companies that acquire forest land for conversion to agricultural estates without having completed the process of changing its land-use status fully, (iii) local logging gangs controlled by local entrepreneurs with powerful backing and (iv) local people opportunistically occupying land for agriculture, sometimes encouraged by business interests. Thus, they come in two classes: legal or semi-legal (usually by formal business concerns or government agencies) and illegal (usually by informal individuals or groups).

The threat from legal activities comes in three different shapes. First, areas are excised from the forest estate to convert to plantation agriculture. Examples include most of the Tripa Swamp and parts of the Singkil Swamp, all prime orang-utan habitat (for locations, see van Schaik et al., 2001). Most of these decisions predate the declaration of the Leuser Ecosystem in 1995.

Second, poor co-ordination between government agencies or lack of knowledge of the legal status of land may lead to decisions that contradict decisions made by other government agencies. For instance, transmigration areas 

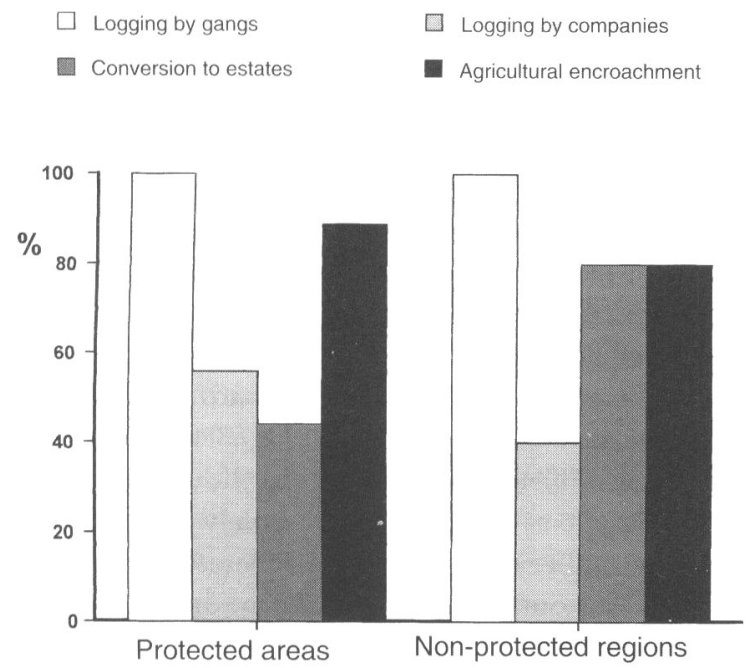

Fig. 2 Percentage of protected areas $(n=9)$ and of nonprotected regions $(n=5)$ inside the Leuser Ecosystem affected by illegal logging by gangs or companies, illegal agricultural encroachment, and illegal or semilegal conversion to agricultural plantations. Protected areas include all wildlife reserves (Rawa Singkil, Kluet Selatan, Gunung Leuser, Kapi, Sikundur, and Langkat), nature recreation forest (TWA Gurah, TWA Bohorok), and protection forest inside the designated National Park (HL Serbolangit). Non-protected regions cover the remaining area of the ecosystem in geographical blocks, not related to legal categories, and include some protection forest, though none are delineated or gazetted as such (Bengkung-Sembabala, Kluet Utara, Ie Merah-Krueng Meureubo, Bidin-Jambo Aye-Serbajadi-Lesten, Rawa Tripa-Kuala Batee).

are sometimes planned in forests on deep peat or steep slopes that should be protection forests under general laws. The LMU is addressing this problem by improving interagency co-ordination on land-use decisions, but it is important to note that, although the Leuser Ecosystem is almost entirely comprised of state forest land, about onethird of it can be legally logged or converted to agricultural estates. This comprises $7242 \mathrm{sq} \mathrm{km}$ of timber concessions in non-swamp forest, $595 \mathrm{sq} \mathrm{km}$ of swamp forest in the Tripa area (van Schaik et al., 2001) and $270 \mathrm{sq} \mathrm{km}$ in the Singkil swamp (Decree of the Minister of Forestry No. 166/Kpts-II,1998). This total acreage assumes the reality that areas involved are not protected as they should be, according to general laws.

The third and most common form is semi-legal conversion. This threat arises because the full procedure for transforming land-use status of a tract of land was not followed, even though some local authorities support conversion. The most widespread example of this is the establishment of vast oil palm plantations, coming in on the back of legal logging concession and the road system it created. First, it is common practice for semilegal conversion to proceed on the basis of a letter of application only to the Forestry service. Second, a company obtains a licence legally to clear-fell an area, but then uses it to deforest a much larger area, exploiting administrative weaknesses, as sketch maps do not define clearly the boundaries of their operations. Parts of the Gunung Leuser National Park in the Langkat regency were converted to oil palm plantation by this mechanism. Third, the local government sometimes organizes a local transmigration project or allows villagers to open up agricultural fields on state forest land. All these activities create a fait accompli, and the Minister of Forestry is requested to release the land for agriculture after in fact it has already been converted.

A bizarre example of this semilegal threat concerns 12,000 ha of lowland forest in the Sikundur Wildlife Reserve of the Gunung Leuser National Park, illegally cut in the early 1970s and 1990s and left to regenerate. Although Sikundur has been a wildlife reserve since 1935, during 1998-1999, a religious cultural organization began building a settlement within the park to help poor farmers acquire agricultural land, based only on a letter of application. In actual fact, the group was operating as a front for a local businessman who planned to obtain the land for plantation agriculture (Waspada, 10.08.1998).

The illegal threats come in a variety of forms:

(a) commercial logging companies breaking the regulations, i.e. over-logging; this can be carried out either inside or outside their designated logging concession;

(b) illegal (wildcat) logging inside approved logging concessions; this is usually perpetrated either by local people or by gangs of illegal loggers who parasitize a logging company's concession;

(c) illegal logging by local people or specialized gangs who operate in state forest land outside logging concessions; this includes illegal logging of national parks, forest reserves and protection forest.

\section{Immediate causes of forest destruction}

It is clear from the above account that many processes, from the completely legal to the totally illegal, are degrading the Leuser Ecosystem. Here, we address the immediate causes. Once these are identified, we can focus on the underlying causes and the recommended courses of action. The three most important proximate reasons explaining why orang-utan habitat in the Leuser Ecosystem is being destroyed, in spite of the LMU's efforts, are weak compliance with regulations, weak law enforcement and weak legal environment.

\section{Weak compliance with regulations}

None of the logging concessions operating in the Leuser Ecosystem have approved environmental impact assessments that would pass verification by independent 
experts. For instance, most of the concessions contained significant amounts of forest on slopes above 40 per cent or swamps with peat layers more than $2 \mathrm{~m}$ thick, which by law should be categorized as protection forest (Hutan Lindung). In fact, the majority of the acreage within these legally granted concessions cannot technically be logged or converted if these regulations were complied with (Monk \& Purba, in press). Likewise, when logging concessionaires' annual work plans were officially approved, there were no provisions for monitoring by independent organizations to challenge the decisions made, although many violated the Forestry Department's own regulations. Additionally, logging of adjacent protection forests by logging companies is rampant despite press exposure (e.g. Medan Pos, 11.12.1998; Waspada, 09.02.1998, 07.07.1999; Serambi Indonesia, 02.12.1999a). Concessionaires are rarely fined officially, and none had their licences revoked in spite of major violations, but recently, the licences of some concessionaires have not been renewed.

Most of the saw mills around the Leuser Ecosytem operate without proper permits, processing illegally cut timber. Even those who do have permits, often process illegally cut timber. For example, of at least 46 saw mills processing illegally-felled timber in the Aceh Selatan regency during early 1999, only 18 had official permits to operate in the first place (see Fig. 3 for locations of regencies). Whilst in two districts of the Aceh Tenggara regency, eight saw mills existed solely from the processing of timber cut from the designated National Park for years without being closed down, despite an order from the provincial Governor's office.

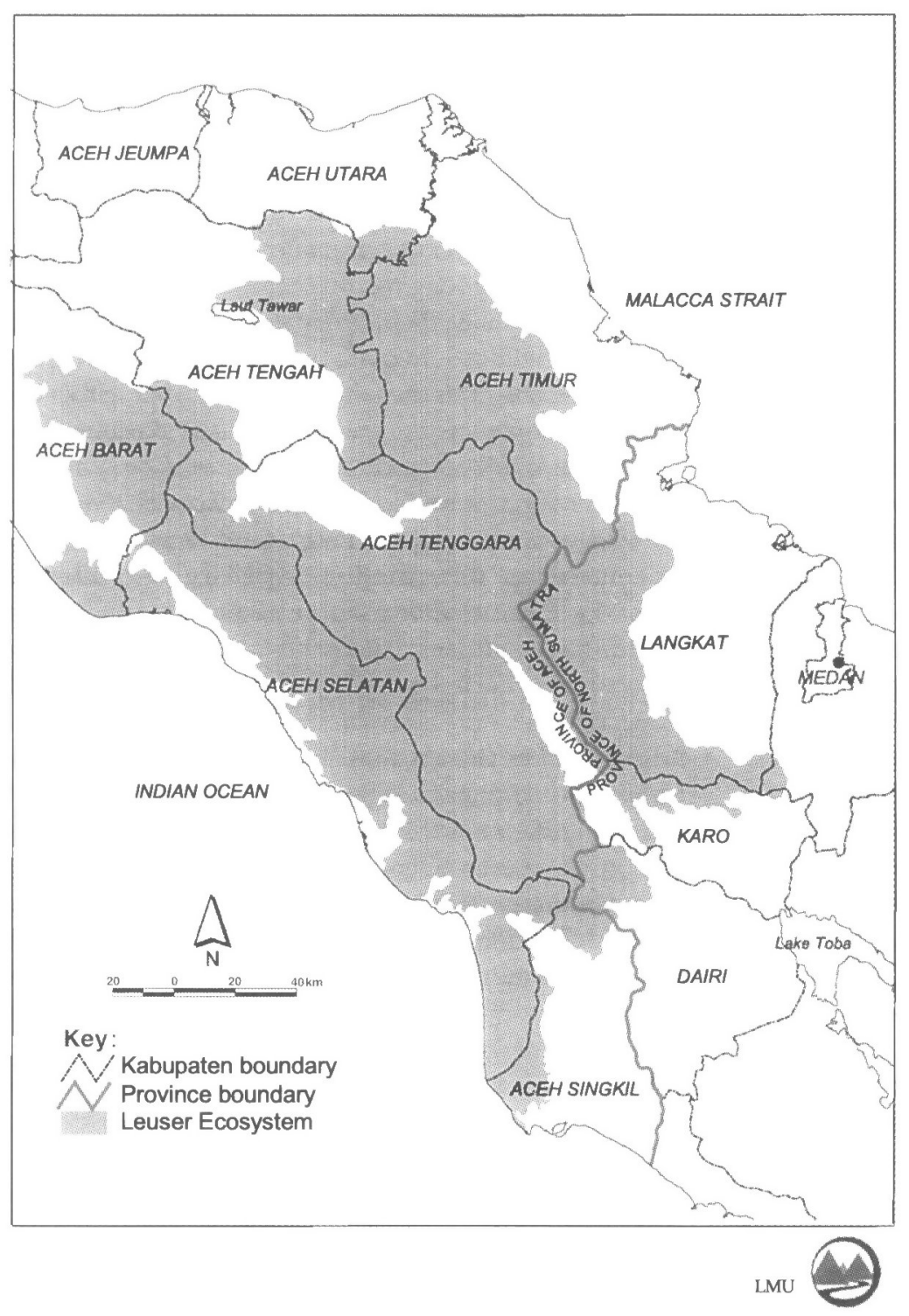

Fig. 3 Map of the administrative boundaries around the Leuser Ecosystem in northern Sumatra, showing both the provincial and regency (Kabupaten) boundaries. (Note: a new regency proposed is called Gayo Lues that would comprise the northern half of the current regency of Aceh Tenggara). 
This shows that the local demand for timber is far in excess of the legal supply. Nationally, between one-half and two-thirds of the total log consumption is sourced from illegal logging (Purnomo, 2000). In the pulp and paper sub-sector, over 100 million cubic metre of wood was consumed since 1987. Less than 5 per cent of this came from sustainable pulpwood plantations, with the remaining 95 per cent obtained from legal and illegal logging of natural forests (Purnomo, 2000). The government has shown its intent to handle this problem by the formation of an Interdepartmental Committee on Forests, as stipulated under Presidential Decree no. $80 / 2000$.

\section{Weak law enforcement}

During the last few years, the ineffectiveness of law enforcement in the Leuser Ecosystem has been reported widely (e.g. see Serambi Indonesia, 11.02.1998; for Aceh Singkil; Analisa, 09.12.1999; Prestasi, 11.12.1999; Waspada, 08.12.1999; for Aceh Tenggara; Analisa, 31.12.1998 and Serambi Indonesia, 02.12.1999a; for Aceh Timur; see also EIA/Telapak, 1999). This ineffectiveness can also be seen easily from the results of enforcement operations supported by the LMU during the 3 years till March 1999. Only three of the 24 enforcement operations in the Leuser Ecosystem, executed at considerable cost, resulted in the perpetrators being held in custody by the police (Table 1). Instead, most of those arrested were released after making a signed statement, none of which resulted in summonses being issued (see also

Table 1 Summary of results of enforcement operations in the Leuser Ecosystem supported by the LDP from March 1996 to March 1999.

\begin{tabular}{llll}
\hline & $\begin{array}{l}\text { Expenditure } \\
\text { (\$US) }\end{array}$ & $\begin{array}{l}\text { Number of } \\
\text { operations }\end{array}$ & $\begin{array}{l}\text { Number of cases } \\
\text { presented to } \\
\text { public prosecutor }\end{array}$ \\
\hline Area & 29,965 & 17 & 0 \\
Aceh & 6095 & 3 & 0 \\
$\begin{array}{l}\text { North Sumatra, } \\
\text { except Langkat }\end{array}$ & 11,855 & 4 & 3 \\
Langkat & 47,915 & 24 & 3 \\
Total & & & \\
\hline
\end{tabular}

Source: Leuser Development Programme (1999).

Notes: 1. Original cost in rupiah (Rp). During the period, the exchange rate fluctuated wildly from Rp. 2250-15,000/\$US. For ease of conversion back to rupiah, an average exchange rate of Rp. $6500 / \$$ is used, corresponding roughly to the cost if converted at date of each contract.

2. About 70 per cent of the cost of each operation comprised per diems for team members. As a result of low government salaries, this could amount to more than double their monthly salaries. The balance comprised vehicle hire, fuel, legal processing and administration/reporting.
Serambi Indonesia, 02.12.1999b; for a different example). The only successful prosecutions were conducted in one regency where enforcement agencies and political authorities supported enforcing conservation laws. Indeed, even when specific cases had been exposed to the press, and letters from the offices of the provincial Governor and the national Director-General for Nature Conservation had been issued, logging often went on for months or years (e.g. at Suaq Balimbing in Aceh Selatan regency; and at Lak-Lak, Badar district, and Luk-Luk, Lawe Alas district, both in Aceh Tenggara regency).

The LMU also supported several community-based protection initiatives, but their effectiveness was severely constrained by the obstruction of the law enforcement apparatus in collusion with the illegal operators (e.g. Waspada, 15.12.1999; Sinar Baru Indonesia, 13.01.2000; Robertson \& van Schaik, in press). In a review of Indonesia's ICDPs (The World Bank, 1997), it was concluded that ICDPs stand little chance of success without at least some effective provision for law enforcement.

\section{Weak legal environment}

The few cases that led to prosecutions did result in convictions (see Table 1), suggesting that the judiciary system can be effective in upholding the law, but overall, prosecutions are strikingly rare. There may be several reasons for this. First, individuals and organizations alike may be discouraged from taking illegal operators to court. Cases may drag on for years, and when forestry agencies prosecute perpetrators, the standard funding allotments quickly run out. Second, prosecuting the organizers of illegal-logging operations is difficult in the absence of a witness protection programme (see The Jakarta Post, 30.04.1999b, for a similar example). Activists, forestry officials, and LMU staff regularly receive death threats and several recent killings are widely thought to be related to illegal logging. Third, it is only since 1997, under Act no. 23, that NGOs can sue the government for breaching its own regulations. This new law is now being tested in court. Finally, as a general deterrent, public distrust in the legal system has led to the assumption that the courts only served the interests of the New Order regime, whose main elements were still in place after the downfall of Soeharto in 1998 (Soedjati, 1999; The Jakarta Post, 04.02.2000; Unidjaja, 2000).

\section{Underlying problems and their political solutions}

Here we identify corruption, frontier mentality and bureaucratic constraints, in order of importance, as the 
major underlying causal factors for the destruction of orang-utan habitat in the Leuser Ecosystem. These factors require political-level intervention and therefore lie outside the scope of the LMU's capability, making it impossible for the LDP to solve the immediate constraints identified above.

\section{Corruption}

Corruption, collusion and nepotism together form the ultimate causal factor underlying the three major immediate factors outlined above that have resulted in the destruction of prime orang-utan habitat in the Leuser Ecosystem. Corruption leads to a climate in which those in control can subvert the legal system, making them virtually untouchable. According to all national newspapers, corruption had invaded almost the whole of public life during the Soeharto and Habibie regimes (see also Colmey \& Liebhold, 1999; The Jakarta Post, 21.06.2000a, b; Winters, 1999). Not surprisingly, Indonesia was ranked as the sixth most corrupt country in the world by Transparency International's Corruption Perception Index for 1998 (The Jakarta Post, 30.04.1999a), and one of the two most corrupt countries in Asia by Political and Risk Consultancy Ltd (The Jakarta Post, 26.03.1999; 23.03.2000). Whilst corruption is found in virtually all countries, the problem becomes debilitating when it is so widespread. The World Bank, for instance, admitted in 1998 that about 30 per cent of all its development aid money to Indonesia, calculated by some analysts as amounting to about $\$$ US 10 billion, had been siphoned off (The Jakarta Post, 15.04.1999, 19.02.2000; Colmey \& Liebhold, 1999). A former finance minister called on the government to dissolve the National Development Planning Board (Bappenas) on the grounds that the government has lost between 30 and 50 per cent of the loans it got from overseas to finance Bappenas' faulty projects' (The Jakarta Post, 28.03.2000).

From the conservation perspective, there are widespread allegations of corruption by two major groups (see also EIA/Telapak, 1999), although few of these allegations have been proven in court. First, the armed forces, a major part of the enforcement apparatus, had taken control of many illegal logging operations and took rents for security guarantees from the legal ones (Serambi Indonesia, 11.02.1998, 28.04.2000; Cohen, 2000; The Jakarta Post, 22.04.2000b, 20.05.2000).

Second, corruption became a potent force within government departments (The Jakarta Post, 24.04.1999, 14.07.1999; Media Indonesia, 28.06.2000) including the Department of Forestry (Analisa, 13.12.1999; EIA/Telapak, 1999; Cohen, 2000; The Jakarta Post, 17.02.2000, 24.02.2000, 07.04.2000, 22.04.2000a, 20.05.2000). A special team established to investigate corruption in the forestry sector, headed by the Secretary-General of the Department of Forestry and Estate Crops, identified a misuse of the department's reforestation funds by concessionaires owned by former President Soeharto's family and cronies (The Jakarta Post, 08.02.2000). The Supreme Audit Agency exposed corruption amounting to Rp. 49.798 billion (c. \$US 7.6 million) in the Department of Forestry \& Estate Crops for the financial year 1999-2000 (Media Indonesia, 28.06.2000).

Forestry officials themselves have hastened the destruction of orang-utan habitat by allowing/backing the conversion of forest, including protected areas, mainly to oil palm plantations. In late 1999, for instance, a group of lawyers in Medan began court proceedings to sue the former Regional Head of Forestry and former Head of the National Park for allegedly giving false information in support of a proposal later approved by the Minister of Forestry (Sinar Baru Indonesia, 13.12.1999). As a result of this approval, a community group backed by an army foundation obtained a concession to log part of the National Park in Langkat (province of North Sumatra) and convert it to oil palm plantation (Prestasi, 02.11.1999; Sinar Baru Indonesia, 02.11.1999).

After Indonesia installed its first democratically elected president in October 1999, a new era to rid the country of corruption began, but by late 1999, the situation on the ground was worse than ever before in many places (EIA/Telapak, 1999; Cohen, 2000). Despite some inroads, corruption is so ingrained that the few changes at the top have as yet had little effect at the lower levels. Thus, action to combat corruption remains critical for conservation. Key actions include creating the political will, rescinding the dual role of the armed forces, creating transparency and accountability of central and local government, linking international loans to progress in forest conservation and promoting awareness.

\section{Political will}

Many integrated conservation and development programmes do not succeed because political decisions beyond their sphere of influence override the local efforts. In the case of LDP, a major part of its early successes was because of its ability to lobby at the provincial and national levels and affect specific policy decisions. For instance, this succeeded in preventing further technically inappropriate transmigration schemes in the Singkil Swamp and the Bengkung, and further official conversion of the Singkil Swamp for agricultural estates. The LMU could not cope, however, with the sheer number of such destructive development proposals. The main obstacles to progress 
remain in the civil service and at the local political level, both of which stand to lose lucrative sources of income. This resistance can be overcome if the political will is strong enough for the government to unambiguously declare its determination to conserve the Leuser Ecosystem and ensure all destructive processes within it are prevented.

The scale of the problem to be overcome was highlighted by the Secretary-General to the Minister of Forestry and Estate Crops, Soeripto. After a 7-month investigation, he concluded that the multi-billion illegal logging business involves not just local government officials and businessmen but also central government officials in Jakarta and members of their networks in Singapore and Hong Kong (The Jakarta Post, $19.08 .2000 \mathrm{~b}$ ). They were accused of purchasing logs stolen from both national parks and logging concessions, as well as playing significant roles in the abduction and assault of activists from several NGOs. It is widely thought that most of the major cases of illegal logging in Leuser, also have links to legislators and political figures at all administrative levels. These figures are at the forefront of anti-conservation declarations, using arguments to increase development for the people as a front to protect their business interests. Thus, strengthening the political will for conservation efforts that take into account the long-term benefits, will require intensive efforts by national and international NGOs, scientific institutions and concerned individuals.

The dual role of the armed forces

During the Soeharto regime, the armed forces had a legally-agreed dual function: security and politics. Under Law No. 4/1999, the armed forces were given 38 unelected seats in the House of Representatives, a reduction from their previous total of 75 . They are also granted 10 per cent of the elected seats in provincial and regency legislatures. As a result of their role in politics, the army controlled most positions of power, which extended into the forestry sector. They became involved in forest exploitation and even officially had many logging concessions. Their involvement in activities they were supposed to be monitoring created a conflict of interest. Rogue members of the enforcement apparatus, especially at the district (Kecamatan) level, became involved in controlling illegal logging operations. This continued throughout 1998 and 1999, although many cases were exposed by the newly unbridled press (e.g. Kompas, 20.04.2000 for Langkat; Analisa, 07.12.1999, 09.12.1999; Prestasi, 11.12.1999; Waspada, 08.12.1999, 09.12.1999, 15.12.1999; Sinar Baru Indonesia, 13.01.2000; for Aceh Tenggara; Serambi Indonesia, 02.12.1999b; 28.04.2000 for Aceh Timur; Serambi Indonesia, 11.02.1998 for Aceh Selatan regencies; see also EIA/Telapak, 1999; Cohen, 2000).

During 1999, the armed forces issued a directive instructing all their personnel to choose between either staying in the military and cutting off all their private business and political ties, or vice versa. Decrees issued by the People's Consultative Assembly to take effect from 18 August 2000 will end the presence of the military and police at the House of Representatives, provincial and regency legislatures in 2004, but maintain their presence at the People's Consultative Assembly until 2009 (The Jakarta Post, 19.08.2000a). These changes should contribute strongly to orang-utan conservation, by eliminating the business involvement and the conflict of interest this entails, but reining in the rogue elements at the lower levels may require strong political will and a good working relationship between their commanders and conservation bodies at the local level.

\section{Transparency and accountability}

The Indonesian government has identified increased transparency and accountability as major tools to eradicate corruption. Such steps will also have a major positive impact on orang-utan conservation. Implementing this at the local and regency level would also have beneficial side-effects for conservation because there are many projects that appear to serve no rational purpose other than providing income from the projects to the officials involved. These plans particularly relate to road-building and transmigration schemes, both of which can destroy prime orang-utan habitat. The local transmigration scheme executed in the Bengkung area for example, placed 300 families some $60 \mathrm{~km}$ away from the main road. The only rational explanation for this scheme is that it would require funds for a roadbuilding project to upgrade the old logging road leading to it.

The government has made major progress recently in approving accountability and transparency through the abolition of the Ministry of Information and far greater press freedom. This can be improved further with independent auditing and right of access to public information (especially, regarding applications for forest use permits three months before they are scheduled for approval). Whilst the government and the press together are clearly exposing many more cases of corruption, progress over prosecution of perpetrators is slower, again highlighting the need to support reforms in the judicial system.

\section{Centralized power}

It is often argued that centralized power has strongly contributed to power abuses and corruption, resulting in forest destruction, but although centralization certainly 
makes deforestation a more intractable problem, the real problem is corruption. Regional government officials are just as likely as central government officials to facilitate conversion of orang-utan habitat to oil palm plantations illegally. Thus, the solution is transparency and accountability.

Whereas there may be strong arguments for local autonomy, conservation is not served by absolute local autonomy, especially because this would eliminate representation of national (and through it the international) interests. For instance, the government of Aceh Tenggara regency has repeatedly proposed to de-gazette 30,000 ha of prime orang-utan habitat in the national park, in order to convert forest to agricultural lands. In the current proposals for regional autonomy, conservation will remain under the control of the central government, whereas exploitation will have substantial local control. This is to satisfy demands for local communities to exploit what they perceive as 'their' forests, possibly based on traditional law (adat).

\section{International loans and forest conservation}

As part of the Supplementary Memorandum of Economic and Financial Policies, Fourth Review under the Extended Arrangement (for text see The Jakarta Post, 17.03.1999), the Indonesian government reported to the International Monetary Fund (IMF), significant progress towards structural reforms in the forestry sector. Nonetheless, regardless of these structural achievements, the Leuser Ecosystem experienced an unprecedented wave of illegal logging throughout 1998 and 1999, and was still subjected to tens of thousands of hectares of orangutan habitat being converted to oil palm plantations (van Schaik et al., 2001). This obviously poses a dilemma for both parties. Whilst recognizing the importance of structural reforms, biodiversity conservation is better served with a more direct link. Consequently, we suggest that disbursement of all major development loans (i.e. excluding humanitarian aid) should be linked to verifiable progress in preventing degradation of all current and proposed protected areas. This is easy to monitor independently, especially with satellite imagery, corroborated by ground truthing by independent bodies led by local NGOs.

\section{Awareness}

The abolition of the Ministry of Information in October, 1999 signified the end of the old regime's control over press freedom. This has increased the ability of the press to expose corruption and cases of illegal destruction of forests. Increasing conservation awareness amongst the public at large is also a major tool to generate the momentum that will convince politicians to take conservation issues seriously. In the long run, strong public support for conservation will be the best guarantee for safe protected areas.

\section{Frontier mentality}

After corruption, the next major underlying reason for habitat destruction is that both local government and business interests view a logging concession as the first step in the development process, which involves land clearing, rather than as part of the permanent forest estate, as intended by the law. Local people and local government alike, often believe that forested land is free land (tanah kosong) that should be open to whoever settles first (Rijksen \& Meijaard, 1999). Accordingly, they see the laws and regulations coming down from the central government as obstacles. The central government is seen, therefore as imposing an opportunity cost on local development whenever it regulates access to, and use of, forested land. Hence, local government and local people feel justified to insist on receiving compensation for not converting forest to agricultural lands. When the central government weakened, following the fall of the Soeharto regime, illegal logging and encroachment increased dramatically.

This frontier mentality hampers development by encouraging unplanned exploitation and conversion without regard of the consequences for ecological services or biodiversity, and without adherence to carefully designed plans that optimize the outcome for the region or nation as a whole.

A possible solution to this problem is to combine a strong emphasis on law enforcement with an equally strong commitment to support appropriate local development through quid pro quo agreements with local communities and their leaders. The key action to set this in motion is for nonemergency development aid to be prioritized to solving all the conservation versus development conflicts around protected areas. This means minimizing, then eventually stopping, all unsustainable exploitation of protected areas. It also requires ensuring all boundaries are marked clearly in the field and local public awareness of protected area boundaries improved.

\section{Bureaucratic constraints}

The third underlying reason for the habitat destruction is bureaucratic constraints. Bureaucratic institutions that control integrated conservation and development projects are generally unable to respond promptly and have limited capacity for adaptive flexibility of response (The World Bank, 1997; The Rainforest Foundation, 1998). This problem can cripple any project through delays in the release of funds and lengthy procedures that create inefficiencies (The World Bank, 1997). For instance, 
during 1998-1999, lack of funds from both donors of the LDP resulted in frequent grounding of field staff and stopping field projects before completion.

More delegation of responsibility and authority for monitoring and evaluating the programme to the appointed EC representation in the country would improve the programme's continuity and therefore its credibility in the field. It would also lead to a stronger involvement at the ambassadorial level and, thus, to stronger lobbying for removal of political obstacles to conservation. Finally, direct project monitoring by the country representation would speed up decision-making and thus lead to improved functional autonomy of the programme.

A further specific problem concerns enforcement operations. The legally authorized personnel to conduct enforcement operations in state forest land are rangers (Jagawana/Polisi Hutan) from the Department of Forestry (formerly the Department of Agriculture and Forestry), usually accompanied by an appointed police officer. The teams must have funds for each operation. Thus, no funds means no enforcement operation, and, as shown previously, no enforcement means no orang-utans. The EC regulations prohibit re-allocation of their project contribution to finance enforcement. Funds from the government, unfortunately, usually arrive several months late in each financial year. For instance, no enforcement operations could be conducted around Leuser for the first six months of the financial years 1999 and 2000 because of delays in the release of government funding. This was also a well-known fact to illegal loggers because of collusion. Consequently, the LMU could do nothing to stop major outbreaks of illegal logging of prime orang-utan habitat.

One long-term solution to this problem could be for the designated management body, the Leuser International Foundation, to be endowed with sufficient funds from private donors to create an effective trust fund, which it then uses to work in partnership with the government to help pre-finance any temporal shortfalls. The short-term solution is for the government to authorize roll-over extensions to budgets.

As a result of special problems of law enforcement in Aceh (see also Waspada, 02.03.2000), these measures alone are unlikely to prevent the current large-scale illegal logging in the Leuser region. Instead, the government should consider establishing a special armed police unit attached to the management body (see Robertson \& van Schaik, in press). In the short term, this requires authorization of part of the government's contribution to the LDP from the state budget to be channelled via the National Police Department. In the long term, this unit could be seconded to the LIF and all operational costs can be funded from the trust fund, which international donors should help establish.

\section{Recommendations}

In this section, we make recommendations for actions that are vital for improving orang-utan conservation in northern Sumatra. The review and analysis demonstrate that the major constraints on LDP's ability to conserve orang-utans are political rather than technical in nature. This by no means indicates that efforts to conserve the orang-utan are doomed to failure. On the contrary, we note that Indonesia has made significant progress over the last 2 years by any standards in history, going from 32 years of military guidance to its first fully democratically elected government, accompanied by major reforms in all sectors. If these reforms were to continue in their present course and the following recommendations implemented in full to allow the LDP to operate effectively, we are optimistic that the Sumatran orangutan's current collision course with extinction can be avoided (see scenario 1 in Fig. 4 of van Schaik et al., 2001). With an estimated 6500 orang-utans left in the Leuser Ecosystem in 1999, and the current rate of loss of 1000 individuals every year (van Schaik et al., 2001), we stress that there is little room for any weakness in the political will to implement these recommendations.

We start with those changes at the political level that are well beyond the reach of any individual programme, but that would greatly facilitate orang-utan conservation by reducing corruption, improving transparency and accountability of all decisions involving land use, and generate broad political support for conservation. These recommendations are limited to those with the most immediate positive impact on orang-utan conservation:

1. lobby the international community to make disbursement of international development loans or grants to Indonesia (i.e. excluding humanitation aid) conditional on preventing degradation of protected areas, as monitored by local- and national-level NGOs;

2. lobby the Indonesian government for complete transparency of Forestry's regulations and decisions ('SK') by ensuring an on-line register is kept that can be consulted by the public, in particular for applications concerning proposed changes in land-use status;

3. lobby the international NGOs to support the capability of local NGOs to challenge in court, illegal activities and proposals by local governments to release protected areas for other forms of land use.

Assuming that these political problems are resolved and illegal threats to the Leuser Ecosystem are reduced, technical challenges remain to be met. The major 
priorities are (i) redesigning the national park to enhance its ability to protect the full biodiversity of the Leuser Ecosystem, including the orang-utans and (ii) restoration of habitat corridors to connect major forest tracts important for orang-utans (see Robertson \& van Schaik, in press). These activities are already planned by LDP, and deserve continued support of the Indonesian government, but the following actions that would strengthen conservation inside the Leuser Ecosystem are also recommended to the government:

1. ensure sufficient funds are provided to prosecute violators of protected areas and thus establish clear legal precedents;

2. ensure sufficient funds are provided for enforcement operations, and in particular, overcome budget shortfalls by authorizing roll-over extensions;

3. ensure that LMU/LIF must be consulted before any changes to land-use status inside the Leuser Ecosystem are made, or logging concessions are renewed or their annual work plans are approved.

In addition to these recommendations to allow the LDP to operate effectively, we should also ensure that the long-term conservation of the region is supported after the end of the scheduled EC contribution to the programme in March 2003. This requires the following measures:

1. lobby the European Union to extend the LDP by a substantial period to give more time for the programme to overcome the setbacks incurred during the period of political instability and thus reach its objectives;

2. lobby international donors to create a substantial trust fund for the LIF to support future management activities after the end of the EC's contribution to the programme.

\section{Acknowledgements}

C.v.S. thanks the Wildlife Conservation Society for sustained funding of orang-utan work. We sincerely thank all staff of the LMU and colleagues who made real sacrifices to help conserve the Leuser Ecosystem and its spectacular biodiversity. We are grateful to Elizabeth Purastiti of the LMU for preparing the maps. The LMU is the implementing body of the Leuser Development Programme, and is jointly funded by the European Union and the Government of Indonesia. We believe that, without this programme, the processes leading to the elimination of all viable populations of the Sumatran orang-utan would already be set in motion. The views expressed in this article are those of the authors alone, and do not necessarily represent the views of any institutions we are associated with. We dedicate this paper to the memories of Sayed Mudahar, whose vision was instrumental in establishing the programme, and Idrusman, naturalist, conservationist and close friend, killed in action.

\section{References}

Analisa (1998) Dishut Aceh Timur diminta ungkap pelaku pencurian kayu di lahan HPH PT. TRD. [The Aceh Timur Forestry Service is asked to uncover the identity of illegal loggers in the PT. TRD logging concession area.] 31.12.1998, 7.

Analisa (1999) Oknum aparat disinyalir dukung pencurian kayu di TNGL. [Certain security officials are suspected of supporting illegal logging activities in the Mount Leuser National Park.] 7.12.1999, 7.

Analisa (1999) Kasus perambahan hutan Leuser: Pangdam dan Kapolda harus tindak anggotanya yang diduga terlibat. [Encroachment in the Leuser forest area: the Regional Military Commander and the Provincial Police Chief must take action against their members who were allegedly involved.1 9.12.1999, 7 .

Analisa (1999) Ratusan organisasi internasional menuntut penghentian perambahan liar di TNGL. [Hundreds of international organisations demand an end to encroachment activities in the Mount Leuser National Park.] 13.12.1999, 7.

Cohen, M. (2000) Wood cuts: illegal logging could stem the flow of aid to Indonesia. Far Eastern Economic Review, 27.01.2000, 20-22.

Colmey, J. \& Liebhold, D. (1999) The Family Firm. Suharto Inc. Time Asia. 24.05.1999.

Delgado, R. \& van Schaik, C.P. (2000) The orangutan (Pongo pygmaeus): behavioural ecology and conservation status: a tale of two islands. Evolutionary Anthropology, 9, 201-218.

EIA/Telapak (1999) The Final Cut: Mlegal Logging in Indonesia's Orangutan Parks. Penebangan Liar Di Kawasan Perlindungan Di Indonesia. Environmental Investigation Agency, London \& Washington, Telapak, Bogor, Indonesia.

IUCN/SSC (1997) Asian Rhinos: Status Survey and Conservation Action Plan. IUCN/SSC Asian Rhino Specialist Group (eds T. J. Foose \& N. van Strien) IUCN, Gland, Switzerland and Cambridge, UK.

Kompas (2000) Sekjen Dephutbun: Yayasan Bukit Barisan terlibat kasus TNGL. [Secretary-General of Department of Forestry \& Estate Crops: Regional Army Foundation involved in Mount Leuser National Park case.] 20.04. 2000, 10.

Leuser Development Programme (1997) Overall Work Plan. Leuser Management Unit, Medan, Indonesia.

Leuser Development Programme (1999) Annual Report of the Leuser Development Programme 1998/1999. Leuser Management Unit, Medan, Indonesia.

Medan Pos (1998) Terjadi di Aceh Timur: Ribuan hektar hutan lindung punah dirambah PT. TRD. [Thousands of hectares of protection forest areas have been cleared by logging concessionaire PT. TRD in Aceh Timur.] 11.12.1998, 5.

Media Indonesia (2000) KKN menonjol di 10 instansi. [Corruption, collusion and nepotism exposed in 10 government agencies.] 28.06.2000, 1.

Monk, K.A. \& Purba, D. (in press) Progress towards collaborative management of the Leuser Ecosystem, Sumatra, Indonesia. In Proceedings of the 2 nd Regional Forum for SouthEast Asia of the IUCN World Commission for Protected Areas. 
Prestasi (1999) Ekses pengrusakan TNGL di Bahorok Langkat: Kepmen diabaikan oleh GubSu dan Kakanwil Dephutbun. [Excess of the damage to the Mount Leuser National Park area in Bahorok Langkat: ministerial decree set aside by North Sumatra Governor and the Head of the Provincial Department of Forestry \& Estate Crops Office.] 2.11.1999, 1, 7 Prestasi (1999) Citra TNI/Polri buruk bila kasus TNGL tak tuntas. [The Military/Police will have a bad image if the Mount Leuser National Park case is not fully settled.] 11.12.1999, 1.

Purnomo, A. (2000) Overcapacity in forestry sector. The Jakarta Post, 27.01.2000, 4 .

Rijksen, H.D. \& Griffiths, M. (1995) Leuser Development Programme Masterplan. The Integrated Conservation and Development Project for Lowland Rainforest In Aceh. IBN-DLO, Wageningen, The Netherlands.

Rijksen, H.D. \& Meijaard, E. (1999) Our Vanishing Relative: The Status of Wild Orang-Utans at the Close of the Twentieth Century. Tropenbos Publications. Wageningen. Kluwer Academic Publishers, Dordrecht

Robertson, J.M.Y. \& van Schaik, C.P. (in press) Securing the survival of the Sumatran orang-utan. Proceedings of the 3rd Great Apes of the World Conference, Kucing, Sarawak, Vol. 2.

van Schaik, C.P., Monk, K.A. \& Robertson, J.M.Y. (2001) Dramatic decline in orang-utan numbers in the Leuser Ecosystem. Northern Sumatra. Oryx 35, 14-25.

Serambi Indonesia (1998) Penebangan hutan Rawa Singkil makin menggila. [Clearing of forest areas in Singkil Swamp becoming more rampant.] 11.02.1998, 5 .

Serambi Indonesia (1999a) Kayu curian itu punya Acan? [Is Acan the owner of the stolen timber?] 02.12.99, 6 .

Serambi Indonesia (1999b) POM belum proses truk TNI angkut kayu curian: 141 kayu Tangkapan diduga milik Acan. [The Military Police have not processed the case of a military truck being used to transport stolen timber: 141 confiscated timber beams allegedly owned by Acan.] 02.12.1999, 7 .

Serambi Indonesia (2000) Menhutbun: Acan babat 4,000 ha TNGL. [Minister of Forestry \& Estate Crops: Acan cleared 4, 000 ha of Mount Leuser National Park.] 28.04.2000, 5.

Sinar Baru Indonesia (1999) Menteri Kehutanan dan Perkebunan akhirnya hentikan pembukaan sawit di TNGL: jalan yang telah dibuka diminta direhabilitasi kembali. [The Minister of Forestry \& Estate Crops finally stops the opening of oil palm plantations in the Mount Leuser National Park area: the cleared path must be rehabilitated.] 2.11.1999, 3 .

Sinar Baru Indonesia (1999) Sidang lanjutan kasus TNGL, hadirkan 6 saksi dari Polres Langkat: Tak seorangpun saksi tahu batas TNGL. [The proceeding of the Mount Leuser Nationai Park case, testimony by 6 witnesses from the Langkat police: None of the witnesses is aware of the National Park boundary.] 13.12.1999, 9.

Sinar Baru Indonesia (2000) Muspida plus sepakat berhentikan perambahan hutan TNGL. [The Local Leadership Council members agree to stop the clearing of forests in the Mount Leuser National Park area.] 13.01.2000, 9.

Soedjati, D. (1999) Judiciary marred by distorted rule of law concept. The Jakarta Post 17.03.1999, 1.

The Jakarta Post (1999) Memorandum of economic and financial policies. 17.03.1999, 5 .

The Jakarta Post (1999) Asian corruption remains serious problem: analyst. 26.03.1999, 10.
The Jakarta Post (1999) World Bank acts firmly. Editorial. 15.04.1999, 4.

The Jakarta Post (1999) No leakage? Editorial. 24.04.1999, 4.

The Jakarta Post (1999a) RI urged to adopt pact to fight bribery in country. 30.04.1999a, 1 .

The Jakarta Post (1999b) Witnesses of Ciamis killing spree threatened. 30.04.1999b, 1.

The Jakarta Post (1999) Ministry uncovers Rp, 2.6, t. graft. 14.07.1999, 1.

The Jakarta Post (2000) Wanted: a good judge. Editorial. 4.02.2000, 4 .

The Jakarta Post (2000) Forest team to probe corruption. 8.02. 2000, 2.

The Jakarta Post (2000) Big names probed for alleged abuse of forestry funds. 17.02.2000, 8 .

The Jakarta Post (2000) WB upbeat government can fight corruption. 19.02. 2000, 1.

The Jakarta Post (2000) Bob Hasan queried over US\$2 b forestry fraud. 24.02.2000, 12 .

The Jakarta Post (2000) Corruption in Asia threatens recovery. 23.03.2000, 8.

The Jakarta Post (2000) 'Bappenas must be dissolved'. 28.03.2000, 9 .

The Jakarta Post (2000) Timber tycoons piling war chests to 'block probes'. 7.04.2000, 8 .

The Jakarta Post (2000a) Former forestry minister questioned over graft case. 22.04.2000a, 2.

The Jakarta Post (2000b) Soldiers accused of extortion. 22.04.2000b, 9

The Jakarta Post (2000) KL firms allegedly involved in illegal timber trade. 20.05.2000, 8

The Jakarta Post (2000a) Gus Dur says Soeharto worth US\$45 billion. 21.06. 2000a, 2.

The Jakarta Post (2000b) Council says KKN remains rampant in administration. 21.06.2000b, 3 .

The Jakarta Post (2000a) Annual session of the People's Consultative Assembly 2000: MPR approves nine decrees, TNI's presence included. 19.08.2000a, 2 .

The Jakarta Post (2000b) Illegal logging involves 'central government officials'. $19.08 .2000 \mathrm{~b}, 3$.

The Rainforest Foundation (1998) Out of Commission: The Environmental and Social Impacts of European Union Development Funding in Tropical Forest Areas. The Rainforest Foundation. London, UK.

The World Bank (1997) Investing in Biodiversity: a Review of Indonesia's Integrated Conservation and Development Projects. The World Bank, Indonesia and Pacific Islands Country Development. Jakarta, Indonesia.

Unidjaja, F.D. (2000) Payoffs prominent in court system. The Jakarta Post, 22.03.2000, 2.

Waspada (1998) Hutan Aceh Timur gundul: dua perusahaan tanpa izin terus beroperasi. [Forests in Aceh Timur destroyed: two companies continue to operate without any license.] 09.02.1998, 6.

Waspada (1998) Ops sikat 98 dan jagawana amankan 80 tersangka perusak kawasan TNGL. ['Clean Out' Operation 98 and forest rangers arrest 80 persons accused of causing damage to the Mount Leuser National Park.] 10.08.1998, 5.

Waspada (1999) PT Inhutani IV backing perambahan hutan lindung. [National Forest company PT Inhutani IV backs up the clearing of protection forest.] 7.07.1999, 5 . 
Waspada (1999) Pencurian kayu di TNGL semakin mengganas: Diduga dibecking aparat. [IIlegal logging activities more rampant in Mount Leuser National Park: Backing up by security officials suspected.] 8.12.1999, 5 .

Waspada (1999) Soal perambahan TNGL: Pangdam I/BB dan Kapolda Aceh harus bertanggungjawab. [Encroachment problem in Mount Leuser National Park: The Commander of Regional Military Command I/BB and the Chief of the Aceh Police must be held accountable.] 9.12.1999.

Waspada (1999) Perambah TNGL forsir kekuatan. [Encroachers in Mount Leuser National Park gathering strength.] 15.12.1999, 5 .

Waspada (2000) Di Panton ada Markas GPK bukan GBPK (GAM). [Headquarters of illegal logging 'Movement' at the Panton, but not Aceh Freedom Movement.] 2.03.2000, 5.

Winters, J. (1999) It pays to think big: history favours dictators who take billions not millions. Suharto Inc. Time Asia. 24.05.1999.

\section{Biographical sketches}

Dr Yarrow Robertson is co-ordinator of the Conservation Management Division of the Leuser Development Programme, Medan, Indonesia. He studied the Socioecology of pigtalled macaques in Leuser for his $\mathrm{PhD}$, and has been co-ordinating conservation activities of the Leuser Management Unit with local communities and enforcement agenices for the past 4 years. He is a member of the IUCN SSC Asian Rhino Specialist Group, and affiliated with the Wildlife Research Group, Department of Anatomy, Cambridge University, UK.

Dr Carel van Schaik is Professor of Biological, Anthropology and Anatomy, and co-director of the Center for Tropical Conservation, Duke University (Durham, NC, USA). A research associate of the Wildlife Conservation Society in New York, he has studied primate behavioural ecology, rain forest ecology and conservation policy, focussing on Leuser, for the past 23 years. He is a member of the IUCN Primate Specialist Group. 